\title{
Looking for Henry: Improvisation and Storytelling in Foreign-Language Theatre
}

\author{
Fiona Dalziel Andrea Pennacchi
}

\begin{abstract}
This article describes the role of improvisation and storytelling in a student production of Shakespeare's Henry VI, Part One at Padua University. It explains why the student directing the play and language instructor chose this challenging piece and how they attempted to increase engagement with the project by involving the participants directly in text adaptation. The article explores the improvisation and storytelling activities proposed to the students, which had the aim of fostering their language competence and creating strong group dynamics while familiarising them with the play. These tasks formed the basis of the final version for performance, which consisted in a selection of the original scenes together with some novel scenes, linked together by short narratives produced by the students themselves. In describing this experience, the authors reflect on the benefits of the multidisciplinary nature of foreign language drama, where influences as diverse as Bertolt Brecht, Peter Brook and Bruce Lee can converge in a truly learner-centred approach to second language acquisition.
\end{abstract}

\section{Introduction}

The reflections that the authors of this paper wish to share with fellow practitioners have been gleaned from their experiences with the Padua University English Drama Workshop (for further details see Dalziel et al. 2011), and in particular from the performance of Roses (the war of ...), the group's own adaptation of Henry VI, Part One by William Shakespeare in 2001. As the programme notes that accompanied the show declared:

The performance is a semi-serious study of Henry VI, Part One, by William Shakespeare. The play tells of the political struggles between English nobles leading up to the famous Wars of the Roses and terrible war between England and France, famous for the role of two heroic figures: the brave Talbot on one side and the heroine par excellence, Joan of Arc, on the other. The English theatre group set out to deconstruct the play, performing a selection of scenes and exploring the potential of the figure of the narrator. The whole group participated in the adaptation of the text and the narrative sections. 
The workshop was an extra-curricular activity and the majority of participants were studying on a four-year degree course in Modern Languages and Literature, ranging from first to fourth-year students. However, there were also members of the group from other faculties such as Political Science. In this particular year, there were 18 participants, of whom three were taking part in the workshop for the third or fourth year, and three for the second year; of the remaining participants, one had attended other acting courses, while the rest had no or very little previous acting experience. The final performance was open to the general public and was attended by friends, family members, university and school staff and students.

The production of this play represented the workshop's first departure from contemporary theatre, although members had previously had a taste of the Bard through Stoppard's 15-minute Hamlet. The role of Fiona Dalziel in the project was that of general co-ordinator and language instructor, while Andrea Pennacchi was responsible for the initial theatrical training of participants and directed the play. This paper will focus on two important features of the workshop, improvisation and storytelling, highlighting how these served to foster the development of students' performance and language skills, and gave them the opportunity to give vent to their creativity and express their emotions.

As Marini-Maio (2010: 239) notes, those involved in full-scale foreignlanguage productions "generally are reluctant to give an authoritative voice to their innovative pedagogical practices", and yet this field, which is by nature interdisciplinary, has the potential to bring together expertise from numerous different areas. In the case described here, the weekly sessions leading up to the final performance were co-taught by two practitioners, bringing to the drama workshop a wealth of wide-ranging interests, experiences and influences. The language instructor had been teaching English to language degree students at Padua University for over ten years and had been coordinating the theatre workshop since its conception three years before. At the time, she was attracted by the social-constructivist view of learning, a perspective which values all learners' previous knowledge in the belief that "reflection on experience can lead to personal change" and that such change occurs in a social context so that "our development will be framed by the relationships and dialogue that are available to us" (Roberts 1998: 44). Thus in her university courses, she was attempting to foster learner reflection on the process of language learning in a collaborative and learner-centred environment. With respect to her own professional development, she was intrigued by the concept of reflective practices in language teacher education and the concept of "ownership". Bailey et al. (1996: 25) argue that the "ownership principle" means "that by giving students a voice in the classroom decision-making process, the teacher fosters a feeling of joint control and personal involvement." The director, on the other hand, was about to embark upon a $\mathrm{PhD}$ in Medieval English Literature, while at the same time keeping alive his interest in the theatre by attending numerous workshops in Italy and abroad. His main influences in that period derived from the actor Mamadou Dioume, directors Peter Brook and Eimuntas Nekrosius, 
and the Italian storyteller Marco Baliani. Another, and perhaps somewhat surprising, source of inspiration was Bruce Lee, including the martial arts expert's following maxims:

- Research your own experience.

- Absorb what is useful.

- Reject what is useless.

- Add what is specifically your own. (our italics)

As will be made clear in this paper, ideas of ownership, coming from very different sources, were guiding principles in the workshop, bringing together the language instructor and director in an approach which placed learner agency, autonomy and identity (Carson in this issue) at the forefront, and allowing the workshop participants to discover things by themselves, so that the sages on the stage were indeed the students themselves.

\section{Choosing Henry}

In selecting texts for full-scale performance, foreign-language theatre practitioners have to take into account the level of competence, aims and interests of participants. Choosing a contemporary text will clearly give students the opportunity to work with language which they may perceive as useful and relevant, especially if their main aim of attending the workshop is that of improving their language skills. Moreover, as Fonio and Genicot (2011: 83) note, the cultural content will probably be "more up-to-date". The workshop described here had strong ties with the university's Department of English and German Language and Literature (see also Dalziel et al. 2011), and the participants were mostly students taking a modern-language degree course with a strong literary focus, including the study of Elizabethan theatre. However, despite the undoubted appeal of Shakespeare for the group, one might have expected the choice of a better-known, more popular play, and one which is easier to perform. In fact, one of the first entries of the logbook that the director kept throughout the two-semester workshop read as follows:

Henry VI, a nasty piece of work. Shakespeare still heavily influenced by Marlowe. English national history, with no interest whatsoever for an Italian audience (except perhaps for the bits with Joan of Arc), a violent and nationalistic soap opera, full of names and characters.

And yet it was the director who had suggested the play to the language instructor for that year's performance, for a number of reasons. During his studies of Beckett, he had been struck by the cleverness of writing theatre in a foreign language in order to escape from all temptation of rhetoric, a temptation 
ingrained in the use of one's mother tongue. At the same time, the multicultural actor and singer Moni Ovadia had praised the then newly-founded English Theatre group, not only because of the enormous teaching opportunities it opened up, but also because it provided a space for acting and telling a story in which the actors (and the director) were distanced from the routine and clichés associated with their native language by expressing themselves in a foreign language, one with a different rhythm, pace and sound. In other words, he had come to appreciate the power of foreign-language theatre in bringing about estrangement, to use Brecht's term. Thus his thoughts turned to a play which he felt to be the most Brechtian of Shakespeare's plays, where Shakespeare appears to be criticising, almost parodying, the cult of the hero (as Brecht does in Galileo). He felt that Henry VI, Part One would provide a very strong distancing effect, especially for an Italian audience, accentuated by the historical distance, and that this would enable the audience to reflect on the nature of power and human conduct. He thought that a possible side effect might be that, not being emotionally involved in the historical events themselves, the students would be able to concentrate on the language, the story and the emotions of the characters.

Proposing Henry VI, Part One to a group of students who were taking part in an extra-curricular activity, where intrinsic motivation was the sole reason for participation was clearly a challenge. Indeed, for the workshop organisers, the appeal of the play lay also in the challenge itself. The text needed to be adapted to make it accessible for an Italian audience; the task of the language instructor and director was to involve the students themselves in this process. As Fonio and Genicot (2011: 83) affirm:

[...] staging a foreign language play that presents a certain degree of linguistic and cultural thickness offers the teacher a series of possibilities when working with students to adapt (part of) the text, to readjust its dialogues for a certain audience, or to study cultural materials from the same area or tradition which could enrich the staging or clarify difficult scenes $[\ldots]$

The following sections will illustrate how, by means of improvisation and storytelling techniques, the student-actors also became student-dramatists, how they got inside the history play and transformed it into something of their own, how they mixed Shakespearean and modern English, and how they finally realised that they all had a story to tell.

\section{Improvising Henry}

Improvisational activities may be introduced into foreign language teaching in a number of different ways, ranging from the use of drama games in the classroom (see for example Maley and Duff 1982) to improvisational theatre workshops (Matthias 2007). When the aim of a drama project is to put on a full-scale production in the target language based on a scripted play, improvisation is often 
an important part of the warm-up activities learners engage in before roles are assigned and parts memorised (MacDonald 2011). Many of the advantages of getting students to improvise are identical to those derived from such activities in theatre education in the mother tongue, including the encouragement of spontaneity, creativity, risk-taking and collaboration to name but a few. As Spolin (1999: 4), in her inspiring exploration of improvisation, reminds us:

Spontaneity is the moment of personal freedom when we are faced with a reality and see it, explore it and act accordingly. In this reality the bits and pieces of ourselves function as an organic whole. It is the time of discovery, of experiencing, of creative expression.

Keith Johnstone, whose work on status has been of great value, reminds us that "every inflection and movement implies a status, and [...] no action is due to chance, or really 'motiveless"' (1981: 33). By introducing the concept of status into improvisation, he argues that scenes can become more "authentic".

For the foreign-language instructor involved in drama projects, it soon becomes clear that many of the benefits that can be derived from improvisational activities fit well with theories and approaches to Second Language Acquisition (SLA) and language teaching. One important feature of improvisation activities is that they represent authentic tasks, although in somewhat different ways depending on their role and aim. First of all, as with simple role-play tasks, learners may be required to improvise "real-life" situations; in the classroom, however, performing these short scenes in front of the class, albeit entertaining, remains a "classroom" activity. In the theatre workshop, when small groups are asked to improvise in front of their peers, they are engaging in a truly authentic drama task. It should be noted, however, that the scenes they act out may at times be far from "real-life": while some activities are based on "ordinary" events from everyday life, others require students to envisage the most far-fetched scenarios, such as a television interview with Little Red Riding Hood, Frankenstein or Joan of Arc. Clear parallels can be drawn between improvisation and task-based learning: learners are provided with the "who" and "where" of a situation, and have to solve a problem successfully (Matthias 2007) in a process that will involve aspects of SLA such as production of comprehensible output, hypothesis testing and negotiation of meaning. It is important to note that the task will be deemed successful if a group manages to engage and amuse their peers, rather than if the teacher/instructor praises their language use. Thus, rather than being afraid of making mistakes, learners will be encouraged to take those risks which are so beneficial to language learning.

"In any form of art we seek the experience of going beyond what we already know" (Spolin 1999: 16). Spolin is speaking about "physicalization", which may be seen as particularly important in foreign-language drama. It is well known that effective communication is dependent on both verbal and nonverbal language, and improvisation brings physical expression to the fore. Learners come to understand the importance of the whole body in communication, and "physical mutual intelligibility" (Fonio and Genicot 2011: 81) is encouraged. 
As MacDonald (2011: 271) notes: "The notion of presence as a whole and complete person is essential to improvisation." Moreover, the element of fun involved also giving learners the opportunity to lower their affective filter (Marini-Maio 2010) and build up their confidence, both in their acting skills and in their language competence (Nunley 2011). The motivation deriving from the sheer hilarity of many improvisation tasks is heightened by the collaboration involved. Spolin (1999: 9) notes that a "healthy group relationship demands a number of individuals working interdependently to complete a given project with full individual participation and personal contribution". This mirrors the view of autonomy in language learning, seen as something implying learning both with and from one's peers (Little et al. 2002).

Language learning also requires the acquisition of pragmatic, or sociolinguistic, competence, which can also be fostered by improvisation activities, especially with Johnstone's (1981) attention to status in mind. As Matthias (2007: 56) affirms, "Role-plays and skits encourage students to understand language as a system of communicative choices". By focusing on the role relationships implicit in any given scene, learners can be helped to understand the subtleties of register variation (Dodson 2002: 161) and to pay attention to appropriate language use. Finally, if the ultimate aim of a drama workshop is the staging of a scripted play, improvisation can also serve the purpose of familiarising students with a literary text and getting under the skin of the characters (Fonio and Genicot 2011). It can be a valuable means of generating ideas for possible text adaptation on the part of the participants themselves (MacDonald 2011; Moody 2002; Hegman Shier 2002), thus fostering what may be termed "devised theatre".

In working towards the student performance of Henry VI, Part One, the director proposed a number of improvisation activities loosely based on the events in Shakespeare's play, in particular on the opening scene, in which three messengers arrive during the funeral of King Henry V, bringing progressively worse news about the war with France (I Henry VI). In the first improvised sketch, which students performed before having read the play itself, the "where" was the kitchen of an unspecified lord, and the "who" were the kitchen staff and three messengers. The instructions were simply that during a normal day's work, three messengers passed by the kitchen one after the other on their way to take their news to members of the nobility; each brought more disastrous tidings than the previous one, just as in the original text. It was the task of those working in the kitchen to react to the news without neglecting their duties. Thus the participants could experience the emotions arising from the text, albeit as players of a different status from those in Shakespeare's first scene.

After having read the first act of the play, the students improvised a variation on this first theme, which forced them to reflect on the tensions emerging right from the start of the play between the Duke of Gloucester and the Bishop of Winchester as a result of their political ambitions. In this improvisation activity, the situation was identical but half of the members of the kitchen staff were asked to pretend to be supporters of Gloucester, while the others were to 
reveal their partiality for Winchester. While the students rushed around the steamy surroundings from one roasting spit to another, what began as simple affirmations of allegiance grew into an outright war of words, which got more and more heated as the amounting failures in France became apparent. The experience was exhilarating for all involved and also served the purpose of highlighting the power struggles of Shakespeare's protagonists. A third and final variation saw the students (most of whom were indeed female) transformed into women of the court, including "lovers" of Gloucester or Winchester, looking at events from a new perspective and once again bickering over preferences.

Improvisational activities such as these saw students actively engaged in their theatrical and language learning, creating characters and expressing emotion with their whole bodies. In other words, they could be said to have been researching their own experience (to go back to the Lee's maxims quoted above), or, in a social constructivist perspective, making sense of previous knowledge by means of social interaction. At the same time, they became familiar with some of the underlying themes of the text, such as the petty squabbles arising from the desperate struggle for political power, and yet these were accompanied with a great deal more laughter than one might expect from one of Shakespeare's history plays.

\section{Telling Henry}

One of the entries in the director's logbook read: "C'e molto racconto in Shakespeare", which can be translated as "There's a lot of story in Shakespeare". This reflection led to the decision to help students get into the play by means of storytelling. To start with, after having read the entire play (most students using an edition which had the Italian translation alongside the original), participants were asked to tell the group members which was their "favourite" scene of all. They were given a week to prepare to tell the story of this scene, which they did sitting in a circle on the stage; the story was to last no longer than 3 or 4 minutes. The benefits of such an activity were numerous: the students realised that telling a story effectively so as to convince their peers that theirs really was a "great" scene was challenging, especially in the target language. It involved their overall communicative competence but also narrative skills such as selecting what exactly to "tell" and transforming one scene into a complete story, with beginning, middle and end. As Johnstone (1981: 113) notes, university students may not understand storytelling as well as small children do, so the activity aimed to help them to re-discover and re-acquire a skill perhaps lost over the years. Another vital component was that of listening; very often when pair or group work is carried out in the foreign-language classroom, learners are so intent on their own contribution that they do not pay attention to their peers, thus depriving the communicative event of authenticity. Yet, as the director noted at the time "in order to tell a story, we all must learn to listen to stories", and the result was that the storytelling activity came to resemble in some ways a "group therapy session" (director's logbook). A final 
task consisted in attempting to tell the entire plot of the play in less than two minutes: those brave enough to take up the challenge were rewarded with their peer's appreciative laughter.

A further storytelling-related activity proposed by the director was inspired by Marowitz (1990). Students were asked to choose extracts from the monologues of the play, learn them by heart and perform them in front of their peers in a variety of ways or in different imagined settings. So a "story" from the play could be told in a hurry, as a fairy tale or whilst drinking coffee, re-arranging a room, looking for something, singing or cleaning the floor. One memorable example was that of the chivalric hero Talbot announcing his plans to surprise the French in Orléans as if he were selling Tupperware. Making use of the concept of estrangement, the activity had a surprisingly quick and strong effect on the students' skills: by concentrating on an action incompatible with the words spoken to the point of absurdity, they resisted the temptation to "over-act" which can be strong in the rendition of monologues, and acquired a higher degree of naturalness in their language use. In this way, they managed to get closer to the characters they were playing, moving in the direction of a combination of distance and empathy, which characterises the performances of the Italian storyteller Marco Baliani (Marini-Maio 2011), whose work the director greatly admires. The final aim of the storytelling tasks was to help the group decide to select scenes from the original play for their adapted version. At this point the students had absorbed what they felt to be useful and so could proceed to reject what they deemed useless. This will be further explored in the following section.

\section{Assembling Henry}

Quando metti in scena Shakespeare hai sempre l'impressione di costruire giocattoli con pezzi di bomba atomica.

When you put on Shakespeare, you always get the impression that you are building toys out of pieces of an atomic bomb.

(director's logbook)

The activities described above helped students to acquire an idea about their own Henry, but what they had in their hands was a jigsaw which still had to be pieced together. In the process of assembling the pieces, the students first picked the scenes of the play they wished to perform, basing their choices on the improvisation and storytelling activities they had taken part in. These scenes were then shortened and the language simplified by the language instructor (see Dalziel at al., 2011, for how in later years, this process was also undertaken by the participants themselves). To these, the students added others that were original and inspired by their improvisations. For example, we saw the English preparing to attack the French in a Second-World War bunker, with red and 
blue magnets being moved around a whiteboard to indicate losses and gains of cities.

The scenes were stitched together with short narratives providing the missing details required for the audience to follow the plot; these were written by the students who were to perform them and thus the participants themselves became the playwrights. For example, after the first scene, the student playing the part of the Bishop of Winchester remained on the stage and was joined by one of the messengers. Their narrative began as follows:

A: Paola, do you think they understand what's going on?B: Well, I mean, it's a bit of a mess. It took us two months to make sense of the story.A: I told Andrea the story was too complicated. There are too many characters!B. He's the director.A. We need a way to make the plot clearer.B. Yes, the war, the French against the English. A: It's like a chess game isn't it? The narrators did not merely tell a story, but they had their own persona and saw events from a particular perspective. The student playing the Countess of Auvergne's maid (her Porter in the original play) started her story by bemoaning the fact that she had only two lines to say. To cap it all, after launching into her interpretation of the events, she was rudely interrupted:

Maid: While here in France everything seems to be calm, the seeds of the War of the Roses are growing [...] Richard Plantagenet chooses a white rose while the Duke of Somerset goes for red. But they have to be careful because a white rose can soon become red, with blood.Messenger (arriving with a red and a white rose in her hand): This is the very beginning of the famous war of the Roses.Maid: Who are you?Messenger: The messenger.Maid: Sorry? Who? Messenger. Act one, scene one. Meanwhile, Winchester ... Maid: What are you doing here?Messenger: My part.Maid: Well, I don't think so! Messenger: Will you stop interrupting me.Maid: I only had two lines!In all the narratives, students drew inspiration from both the improvisation and the storytelling activities; they tried to link distance with emotion in a play which they had adopted as their own.

\section{Conclusion}

As Carson (in this issue) points out, language skills can be greatly enhanced by a combination of the rehearsed and the spontaneous. This article has attempted to show how even when the ultimate aim of a foreign language drama project is a product in the form of a full-scale performance, improvisation and storytelling can play an important role in making the process as, if not more, important. As Hegman Shier (2002: 188) suggests: "Innovations that grow out of the rehearsal process often find their way into final performances, a reminder that this is process over product". The activities outlined in this article can also help students to acquire in-depth knowledge of and important insights into the text and, by means of various distancing techniques, to focus on story and emotion. In doing so, students can move towards that ownership of the product which is deemed to be of great value by practitioners involved in theatre in education, in 
language learning and in foreign-language drama (Moody 2002). To go back to one of the director's initial sources of inspiration, Bruce Lee, the participants in the workshop started off from their own experience, and most certainly added something specifically their own. In the language instructor's view, the whole approach adopted was in line with social-constructivist views of learning as they themselves assembled the play through collaboration and interaction, making choices and taking risks. As a result, the contribution of the practitioners was not one of imparting knowledge and passing on techniques, but of fostering an environment where they could become co-owners of the play, along with the students. So, did we find Henry? In the end, the audience enjoyed the show; it was full of "sound and fury", and there was much laughter too. The student actors stormed through the deconsecrated church in which the performance was held, waving sticks and flags, shouting lines in English, but nobody got hurt.

\subsection{Bibliography}

Primary literature -

Shakespeare, William (1962): The First Part of King Henry VI. Ed. by Andrew S. Cairncross. London and New York: Routledge

Secondary literature -

Carson, Lorna (2012): The role of drama in task-based learning: agency, identity and autonomy. In: Scenario, VI/2

Bailey, Kathleen M.; Bergthold, Bret; Braustein, Belinda; Fleischman, Natasha Jogodzinski; Holbrook, Matthew P.; Tuman, Jennifer; Waissbluth, Ximena; Zambo, Leslie J. (1996): The language learner's autobiography: Examining the "apprenticeship of observation". In: Freeman, Donald; Richards, Jack C. (eds.): Teacher Learning in Language Teaching. Cambridge: Cambridge University Press, 11-29

Dalziel, Fiona; Santucci, Anna; Spedo, Giampaolo (2011): Rewriting the Duchess of Malfi: Adapting Webster's tragedy for an ESL drama production. In: Scenario V/1, 5-20

Dodson, Sarah L. (2002): The Educational Potential for Drama for ESL. In: Bräuer, Gerd (ed.): Body and Language. Intercultural Learning Through Drama. Westport, CT: Ablex Publishing, 161-179

Fonio, Filippo; Genicot, Geneviève (2011): The compatability of drama language teaching and CEFR objectives - observations on a rationale for an artistic approach to foreign language teaching at academic level. In: Scenario V/2, 71-85 
Hegman Shier, Janet (2002): The Arts and the Foreign/Second Language Curriculum: An Interdisciplinary Approach to Actively Engage Students in Their Learning. In: Bräuer, Gerd (ed.): Body and Language. Intercultural Learning Through Drama. Westport, CT: Ablex Publishing, 183206

Johnstone, Keith (1981): Impro: Improvisation and the Theatre. London: Methuen

Little, David; Ridley, Jennifer; Ushioda, Ema (2002): Towards greater learner autonomy in the foreign language classroom. Dublin: Authentik

MacDonald, Ian Andrew (2011): Making This Up As We Go: Using Improvisational Theater in Foreign Language Learning. In: Ryan, Colleen; Marini-Maio, Nicoletta (eds.): Dramatic Interactions: Teaching language, Literatures, and Cultures through Theater - Theoretical Approaches and Classroom Practices. Newcastle upon Tyne: Cambridge Scholars Publishing, 270-294

Maley, Alan; Duff, Alan (2005): Drama Techniques: A Resource Book of Communication Activities for Language Teachers. Cambridge: Cambridge University Press

Marini-Maio, Nicoletta (2010): Full-Scale Play Production: Filling the "Empty Space" between Language and Literature with Fo and Pirandello. In: Marini-Maio, Nicoletta; Ryan-Scheutz, Colleen (eds.): Set the Stage! Teaching Italian through Theater. New Haven and London: Yale University Press, 239-266

Marini-Maio, Nicoletta (2011): Re-creating Antigoni: Promoting Intercultural Understanding through Empathy. In: Ryan, Colleen; Marini-Maio, Nicoletta (eds.): Dramatic Interactions: Teaching language, Literatures, and Cultures through Theater - Theoretical Approaches and Classroom Practices. Newcastle upon Tyne: Cambridge Scholars Publishing, 295326

Marowitz, Charles (1990): The Marowitz Shakespeare. London: M. Boyars

Matthias, Bettina (2007): "Show, don't tell!" Improvisational Theater and the Beginning Foreign Language Curriculum. In: Scenario I/1, 44-57

Moody, Douglas J. (2002): Undergoing a Process and Achieving a Product: A Contradiction in Educational Drama. In Bräuer, Gerd (ed.): Body and Language: Intercultural Learning Through Drama. Westport, CT: Ablex Publishing, 135-160 
Nunley, Charles (2011): Présences partagées: Design and Implementation of an Advanced-Level Course in French Theater. In: Ryan, Colleen; Marini-Maio, Nicoletta (eds.): Dramatic Interactions: Teaching language, Literatures, and Cultures through Theater - Theoretical Approaches and Classroom Practices. Newcastle upon Tyne: Cambridge Scholars Publishing, 184-204

Roberts, Jon (1998): Language Teacher Education. London: Arnold

Spolin, Viola (1999): Improvisation for the Theater. A Handbook for Teaching amnd Directing Techniques. $3^{\text {rd }}$ edition. Repr. 1963. Evanston, IL: Northwestern University Press 